Article

\title{
A Lymnaea stagnalis Embryo Test for Toxicity Bioindication of Acidification and Ammonia Pollution in Water
}

\author{
Robert Mazur ${ }^{1, *}$, Wu Shubiao ${ }^{2}$, Krzysztof Szoszkiewicz ${ }^{3}$, Dawid Bedla ${ }^{4}$ and Agata Nowak ${ }^{3}$ \\ 1 Department of Geoinformation Photogrammetry and Remote Sensing of Environment, \\ Faculty of Mining Surveying and Environmental Engineering, AGH University of Science and Technology, \\ Krakow 30-059, Poland \\ 2 Department of Agricultural Engineering, China Agricultural University, Key Laboratory of Clean Utilization \\ Technology for Renewable Energy, Ministry of Agriculture, Beijing 100083, China; wushubiao@gmail.com \\ 3 Department of Ecology and Agricultural Environment Protection, Poznań University of Life Sciences, \\ Poznań 60-649, Poland; kszoszk@up.poznan.pl (K.S.); agata.nowak1992@gmail.com (A.N.) \\ 4 Department of Ecology, Climatology and Air Protection, Faculty of Environmental Engineering and Land \\ Surveying, University of Agriculture in Krakow, Krakow 30-059, Poland; d.bedla@ur.krakow.pl \\ * Correspondence: mazur@agh.edu.pl; Tel.: +48-533-780-911
}

Academic Editor: Maria Filomena Camões

Received: 2 May 2016; Accepted: 12 July 2016; Published: 16 July 2016

\begin{abstract}
The paper presents a study leading to a new acute toxicity test on embryonic and juvenile organisms of the great pond snail (Lymnaea stagnalis Linnaeus). Sulfuric acid, nitric acid, and ammonium hydroxide were used as waterborne toxicants in laboratory experiments. The exposure time was $24 \mathrm{~h}$. Tests were conducted in 5-10 replications for each toxicant. The toxicity of the substances was classified according to different scales and the test's sensitivity was compared to that of the commonly used bioindicator Daphnia magna Straus. The assessment of toxicity impact was supported by microscopic observations. The probit method was used as a parametric statistical procedure to estimate $\mathrm{LC}_{50}$ and the associated $95 \%$ confidence interval. Our study showed that the early developmental stages of Lymnaea stagnalis are very sensitive bioindicators, making it possible to detect even very low levels of the above-mentioned water toxicants. The highest toxicity is shown by ammonium hydroxide with $\mathrm{LC}_{50 / 24 \mathrm{~h}}$ values, respectively, 24.27 for embryos and 24.72 for juvenile forms, and the lowest is shown by nitric acid ions with $\mathrm{LC}_{50 / 24 \mathrm{~h}}$ values, respectively, 105.19 for embryos and 170.47 for juvenile forms. It is highly cost-effective due to simple and efficient breeding and the small size of the organisms in the bioassay population. Compared with Daphnia magna, relatively low concentrations of toxicants caused a lethal effect on embryonic and juvenile organisms of the great pond snail. Owing to their common occurrence and sensitivity, early developmental forms of Lymnaea stagnalis can be a valuable new tool in biomonitoring of the freshwater environment.
\end{abstract}

Keywords: acute toxicity test; bioassay; bioindicators; water pollution; aquatic molluscs

\section{Introduction}

Acidification and ammonia contamination of water resources are currently recognized as serious environmental problems. Water acidification, in most cases, is associated with anthropogenic emissions of sulfur and nitrogen oxides and is addressed from a global perspective [1]. Ammonia content in water is increasingly being recognized as a pollutant of key environmental concern. This toxicant contributes to several environmental problems, including direct toxic effects on water communities leading to eutrophication and acidification of sensitive ecosystems, which affect the health of human beings as the final consumers [2]. Run-off and atmospheric emissions of this toxicant are increasing rapidly in 
many parts of the world, so these environmental concerns are expected to intensify in the future [1,2]. The effects on aquatic ecosystems are difficult to predict and highly variable, depending on many factors. The use of appropriate bioindication methods facilitates more comprehensive determination of their negative impact on the aquatic community.

The effect of acidification has not been universally recognized as dangerous [3,4]; however, the unfavorable environmental effects of acid rain on surface waters have recently been described in a comprehensive manner by many authors [5-11]. Reports of the growing threat associated with the environmental effects of acid deposition have focused mainly on monitoring of changes in freshwater communities. The negative impact of acidification on different aquatic organisms-plants and phytoplankton (producers), invertebrates, and vertebrates-has been widely reported [4,12-22]. All of these studies focused on the analysis of aquatic communities and transformations in populations due to the decrease in $\mathrm{pH}$ caused by acidification of waters from various sources.

Rapid pH changes and significant content of $\mathrm{NOx}$, as well as $\mathrm{SO}_{4}{ }^{2-}$ and $\mathrm{SO}_{3}{ }^{2-}$, may lead to the extinction of many aquatic communities. Depending on $\mathrm{pH}$, the rate of withdrawal of different species varies and additionally depends on their tolerance to environmental stress factors, as well as their developmental stage. Ubiquitous species show tolerance for low $\mathrm{pH}$ values and can survive; however, a decrease in biodiversity can be seen in ecosystems where highly-tolerant organisms are predominant [23-25].

Pollution with ammonia compounds entails the opposite of acidification, i.e., alkalization. It poses a threat because it is highly toxic for most aquatic organisms and is unfortunately quite common, often coming from anthropogenic sources.

At increased concentrations ammonia halts the development and reproduction of various species. It strongly affects internal organs. At low concentrations ammonia ions increase eutrophication of water, and acts as a source of nitrogen for algae [26-29].

The physiological effects of acidification and alkalization on water organisms have been extensively studied in various research centers. Among the toxic effects of decreased $\mathrm{pH}$, at least four main physiological functions are disturbed by high concentrations of $\mathrm{H}^{+}$ions: (Figure 1).

1. Calcium regulation: very important, particularly for invertebrates_crustaceans and mollusks. At low $\mathrm{pH}$ calcium uptake is particularly difficult, which slows down and disturbs the formation of the outer skeleton $[19,30]$.

2. Sodium regulation: vital for most aquatic animals because it plays a key role in ion balance and osmoregulation processes [4].

3. Respiration: particularly at the cellular level, $\mathrm{pH}$ change inhibits galactosidase. By applying enzymatic tests using fluorescence, we can evaluate the degree of disturbance [4,19].

4. Acid-base balance: closely related to other processes, its disturbance can secondarily disturb the basic physiological functions of organisms [4,19].

Changes in $\mathrm{pH}$ are also linked to toxicity of trace metals, which depending on $\mathrm{pH}$ may become more bioavailable and, thus, dangerous for organisms. A slight variation in $\mathrm{pH}$ is not likely to have a direct impact on life in a water ecosystem, but significantly influences the availability and solubility of all chemical forms in fresh water and may aggravate nutrient problems [25,31,32]. At $\mathrm{pH}=5$ a high concentration of aluminum in the water becomes toxic for many invertebrates and fish by disturbing gill function [33]. A group of aquatic mollusks belongs to organisms particularly sensitive to $\mathrm{pH}$ changes, mainly its fall below 7. Surface waters of low $\mathrm{pH}$ are also characterized with low calcium concentrations. Tolerance of various mollusk species to $\mathrm{pH}$ in acidic waters is changeable and ranges from 6.5 to 4.0. On average, in water of $\mathrm{pH}$ below 5.4 populations of aquatic snails die out as a result of reproduction disturbance and disturbance in shell development. Temporary (short lasting) $\mathrm{pH}$ changes can be tolerated in a wider range-up to 3.5 [19]. 


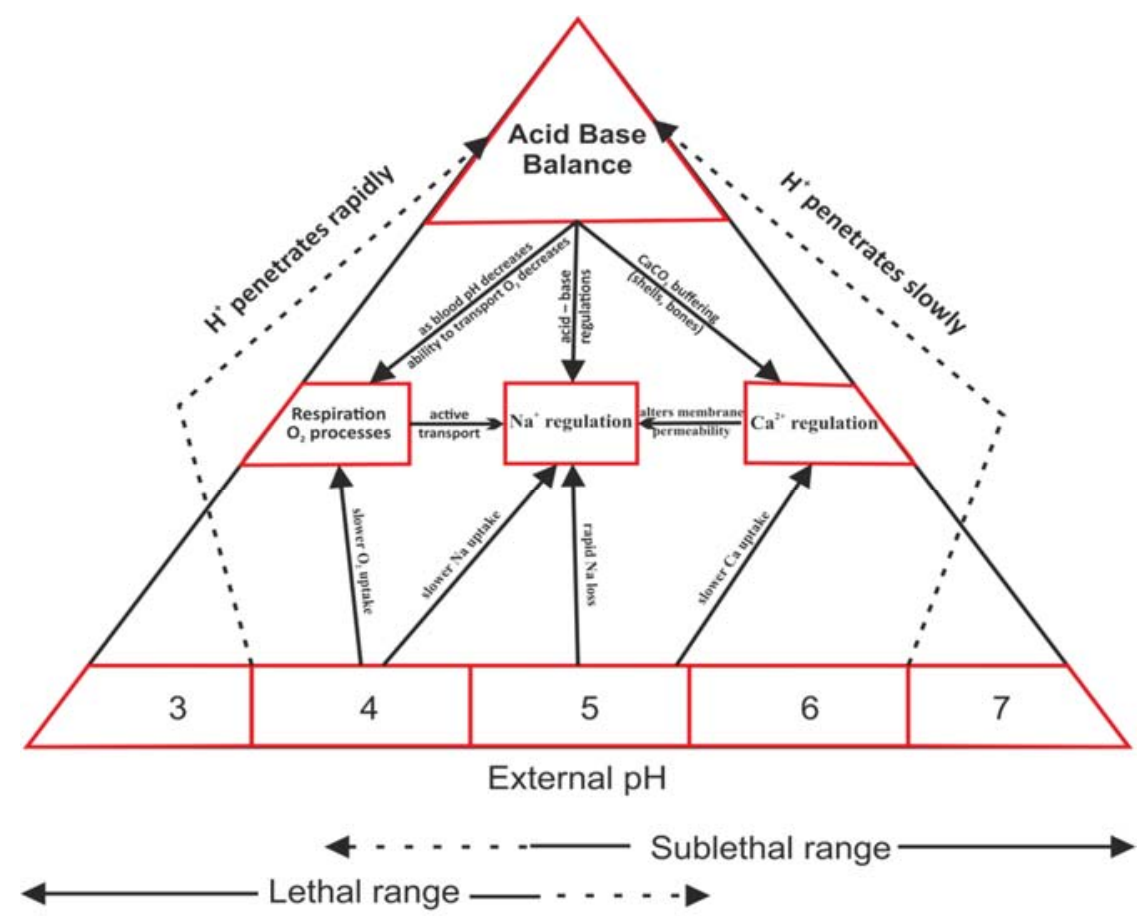

Figure 1. Diagram of the physiological response of aquatic organisms to decreased $\mathrm{pH}$ in the water environment.

Adult developmental stages are more tolerant to decreases in $\mathrm{pH}$ than embryonic and juvenile forms. In some cases embryos develop in eggs, sometimes additionally covered with cocoons; however, their environment is rapidly altered and acidified during hatching. The shock causes high mortality in larvae and juveniles [34,35]. Various amphibian species are particularly sensitive to acidification of water bodies; thus, at the embryonic stage, an increased mortality rate is observed as a result of fungal infestation of eggs and a lack of oxygen, as well as disturbed osmoregulation [36]. A pH level of 5-6 or lower has been considered to be directly toxic to fish [37].

Water acidification and ammonia contamination are among the most common forms of water pollution worldwide. Their concentrations are variable in surface waters and their negative effects on water ecosystems are difficult to predict. Hence, new sensitive bioindication methods are needed. We have conducted a study on the use of the aquatic invertebrate Lymnaea stagnalis as a widely-distributed organism in freshwater ecosystems all over the world. The main objective of the study was to develop innovative bioindication methods which can be widely introduced in water biomonitoring. We proposed the use of embryonic and early juvenile stages of Lymnaea stagnalis. This method was applied in this study for bioindication of both acidification and ammonia contamination in water. The sulfuric and nitric acid solutions selected for testing are major acid rain components [38,39].

\section{Materials and Methods}

\subsection{Selected Bioindicators}

Juvenile and embryonic forms of Lymnaea stagnalis were selected for the analyses, and parallel tests on Daphnia magna were conducted for the same pollutants (Table 1). The response of Lymnaea stagnalis was compared with that of Daphnia magna.

Lymnaea stagnalis, the great pond snail (Figure 2), is a cosmopolitan species, common in all types of freshwater bodies [40]. The snails were obtained from breeding stock in small ponds. Under natural conditions they are found in ponds and lakes and are very common in our climate zone. Full embryonic development in this species takes place in eggs laid in cocoons on leaves or other 
surfaces. In its early developmental stages (embryos and hatchlings) Lymnaea stagnalis is sensitive to changes in the chemical conditions of the water. Thus, these stages make it a good bioindicator for many chemical substances [40]. In the first stage of the experiment the specimens were adapted to laboratory conditions, until the third generation. After the adaptation period pilot tests were performed for a specific group of toxins.

Table 1. Lymnaea stagnalis and Daphnia magna classification.

\begin{tabular}{ccc}
\hline & Species Classification & \\
\hline Kingdom: & Animalia & Animalia \\
Phylum: & Mollusca & Arthropoda \\
Subphylum: & - & Crustacea \\
\hline Class: & Gastropoda & \\
& clade Heterobranchia & Branchiopoda \\
(unranked): & clade Euthyneura & \\
& clade Panpulmonata & \\
\hline Order: & clade Hygrophila & Cladocera \\
Superfamily: & Hygrophila & - \\
Family: & Lymnaeoidea & Daphniidae \\
Subfamily: & Lymnaeidae & - \\
Genus: & Lymnaeinae & Dymnaea \\
Binomial name: & Lymnaea stagnalis (Linnaeus, 1758) & Daphnia magna (Straus, 1820) \\
\hline
\end{tabular}

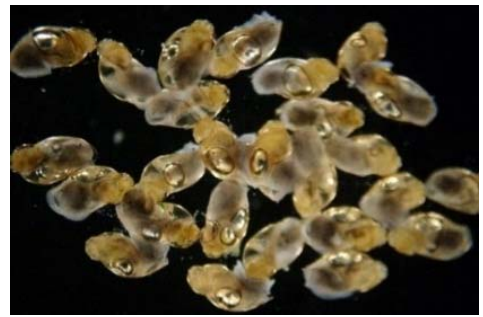

(a)

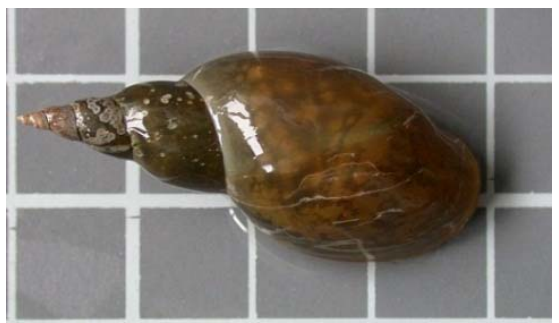

(b)

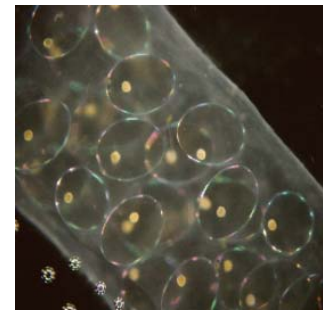

(c)

Figure 2. Lymnaea stagnalis. (a) Juveniles (2-3 mm long); (b) adult (3-5 cm); and (c) a cocoon with embryos developing in the eggs (length of cocoon: $1-4 \mathrm{~cm}$; diameter of egg: around $1 \mathrm{~mm}$ ).

Daphnia magna is the most widely used organism in water bioindication. The selected forms of Daphnia magna were juvenile, up to the age of $24 \mathrm{~h}$, with no signs of morbidity or developmental abnormalities.

\subsection{Culture Techniques and Experimental Procedures on Lymnaea stagnalis}

A laboratory culture of the Lymnaea stagnalis population was conducted at the Laboratory of Environmental Biotechnology and Ecology, AGH University of Science and Technology in Krakow. Adult forms of Lymnaea stagnalis were kept in covered rectangular 21-L aquariums. Constant parameters were maintained in the snail culture.

Water temperature ranged from $22^{\circ} \mathrm{C}$ to $18^{\circ} \mathrm{C}$. Each aquarium was supplied with continuously aerated de-chlorinated tap water filtered through an active carbon reactor.

The $\mathrm{pH}$ value was about $7.0 \pm 0.5$. The light period was controlled ( $12 \mathrm{~h}$ light and $12 \mathrm{~h}$ darkness).

The snails were fed green lettuce leaves every three days. Each aquarium was cleaned by siphoning every week to remove feces. All of the snails in the tanks exhibited high reproductive potential. Adult snails laid their cocoons with eggs, attached to the walls of the aquarium. 
The average number of eggs laid in a cocoon was $70 \pm 30$, but only cocoons with 60-90 eggs were selected to experiment. All of the embryos in cocoons selected for tests were in good condition. Selection was preceded by microscopic evaluation of vital parameters. Unfertilized eggs or those with immobilized embryos were removed.

Sulfuric acid (VI), nitric acid $(\mathrm{V})$, and ammonium hydroxide were applied as toxicants. The concentration of toxicants covered a wide range, from lethal (100\% mortality) to total survival (100\% survival) over $24 \mathrm{~h}$.

Embryo toxicity bioassay procedure: snail eggs were collected and cocoon envelopes were macerated to improve penetration of water with toxins to the inside, but no egg was damaged. Mechanically pre-treated embryos in the cocoons were immersed in the toxicants and exposed to them for $24 \mathrm{~h}$. It took about 15-20 s to open cocoons, but the entire maceration operation was provided in the tested solution, so no other factors have an impact on the developed embryos. For each experimental population, control group, and suitable number of concentrations of toxicant solution were used to determine EC50 (Tables 2-4) and the experiments were repeated in five replications for each toxicant concentration.

Table 2. Mortality of tested organisms in a sulfuric acid solution (24 h) (AVG \pm SD).

\begin{tabular}{|c|c|c|c|c|c|c|c|}
\hline \multirow{2}{*}{$\begin{array}{l}\text { Stock Solution } \\
\qquad \mathrm{H}_{2} \mathrm{SO}_{4} \\
\left(\mathrm{mg} \cdot \mathrm{dm}^{-3}\right)\end{array}$} & \multirow{2}{*}{$\mathrm{pH}$} & \multicolumn{2}{|c|}{$\begin{array}{c}\text { Lymnaea stagnalis } \\
\text { Embryos }\end{array}$} & \multicolumn{2}{|c|}{$\begin{array}{c}\text { Lymnaea stagnalis } \\
\text { Hatchlings }\end{array}$} & \multicolumn{2}{|c|}{$\begin{array}{l}\text { Daphnia magna } \\
\text { Neonates }\end{array}$} \\
\hline & & Mortality (\%) & SD (\%) & Mortality (\%) & SD (\%) & Mortality (\%) & SD (\%) \\
\hline 288.1 & $2.23 \pm 0.02$ & 100.00 & 0.00 & 100.00 & 0.00 & 100.00 & 0.00 \\
\hline 228.8 & $2.33 \pm 0.05$ & 100.00 & 0.00 & 100.00 & 0.00 & 100.00 & 0.00 \\
\hline 183 & $2.43 \pm 0.03$ & 100.00 & 0.00 & 100.00 & 0.00 & 100.00 & 0.00 \\
\hline 146 & $2.53 \pm 0.04$ & 100.00 & 0.00 & 74.07 & 0.07 & 62.82 & 0.08 \\
\hline 117 & $2.62 \pm 0.02$ & 93.40 & 0.42 & 37.82 & 0.06 & 21.88 & 0.04 \\
\hline 93 & $2.72 \pm 0.04$ & 73.00 & 0.49 & 19.07 & 0.04 & 14.07 & 0.04 \\
\hline 75 & $2.82 \pm 0.06$ & 41.90 & 1.15 & 6.88 & 0.03 & 8.75 & 0.02 \\
\hline 60 & $2.91 \pm 0.03$ & 6.20 & 1.18 & 3.13 & 0.03 & 7.82 & 0.03 \\
\hline 48 & $3.01 \pm 0.02$ & 1.60 & 1.11 & 1.25 & 0.02 & 3.44 & 0.03 \\
\hline 38.4 & $3.11 \pm 0.04$ & 0.20 & 2.18 & 0.00 & 0.00 & 0.00 & 0.00 \\
\hline 30 & $3.21 \pm 0.04$ & 0.20 & 2.11 & 0.63 & 0.01 & 0.31 & 0.01 \\
\hline 24 & $3.31 \pm 0.03$ & 0.20 & 0.00 & 0.31 & 0.01 & 0.31 & 0.01 \\
\hline Control & $7.00 \pm 0.01$ & 0.30 & 0.00 & 0.00 & 0.00 & 0.31 & 0.01 \\
\hline
\end{tabular}

Table 3. Mortality of tested organisms in a nitric acid solution (24 h) (AVG \pm SD).

\begin{tabular}{cccccccc}
\hline \multirow{2}{*}{$\begin{array}{c}\text { Stock Solution } \\
\mathbf{H N O}_{3}\end{array}$} & $\mathbf{p H}$ & \multicolumn{2}{c}{$\begin{array}{c}\text { Lymnaea stagnalis } \\
\text { Embryos }\end{array}$} & \multicolumn{2}{c}{$\begin{array}{c}\text { Lymnaea stagnalis } \\
\text { Hatchlings }\end{array}$} & \multicolumn{2}{c}{$\begin{array}{c}\text { Daphnia magna } \\
\text { Neonates }\end{array}$} \\
\cline { 3 - 8 }$\left(\mathbf{m g} \cdot \mathbf{~ d m}^{-3}\right)$ & & Mortality (\%) & SD (\%) & Mortality (\%) & SD (\%) & Mortality (\%) & SD (\%) \\
\hline 228 & $2.44 \pm 0.03$ & 100.00 & 0.00 & 100.00 & 0.00 & 100.00 & 0.00 \\
182 & $2.54 \pm 0.05$ & 89.30 & 1.98 & 61.57 & 0.05 & 32.82 & 0.06 \\
145 & $2.64 \pm 0.02$ & 61.70 & 1.63 & 27.19 & 0.05 & 5.63 & 0.02 \\
116 & $2.73 \pm 0.03$ & 33.00 & 1.68 & 4.69 & 0.02 & 0.31 & 0.01 \\
93.3 & $2.83 \pm 0.06$ & 8.10 & 0.93 & 0.63 & 0.01 & 0.31 & 0.01 \\
74.7 & $2.93 \pm 0.04$ & 4.00 & 1.05 & 0.00 & 0.00 & 0.00 & 0.00 \\
59.7 & $3.02 \pm 0.05$ & 0.40 & 0.61 & 0.00 & 0.00 & 0.63 & 0.01 \\
Control & $7.00 \pm 0.02$ & 0.50 & 1.21 & 0.31 & 0.01 & 0.31 & 0.01 \\
\hline
\end{tabular}

Juvenile toxicity bioassay (after hatching): young individuals were collected and immersed in toxicant solutions in $100 \mathrm{~mL}$ plastic containers, 32 specimens to each polystyrene container. The exposure time was $24 \mathrm{~h}$. The toxicity test algorithm was similar as in the case of Daphnia magna. 
Table 4. Mortality of tested organisms in an ammonium hydroxide (24 h) (AVG \pm SD).

\begin{tabular}{cccccccc}
\hline \multirow{2}{*}{$\begin{array}{c}\text { Stock Solution } \\
\mathbf{N H}_{\mathbf{4}} \mathbf{O H}\end{array}$} & $\mathbf{p H}$ & \multicolumn{2}{c}{$\begin{array}{c}\text { Lymnaea stagnalis } \\
\text { Embryos }\end{array}$} & \multicolumn{2}{c}{$\begin{array}{c}\text { Lymnaea stagnalis } \\
\text { Hatchlings }\end{array}$} & \multicolumn{2}{c}{$\begin{array}{c}\text { Daphnia magna } \\
\text { Neonates }\end{array}$} \\
\cline { 3 - 7 }$\left(\mathbf{m g}_{\mathbf{~ d m}} \mathbf{- 3}^{-3}\right)$ & & Mortality (\%) & SD (\%) & Mortality (\%) & SD (\%) & Mortality (\%) & SD (\%) \\
\hline 91.5 & $11.42 \pm 0.04$ & 100.00 & 0.00 & 100.00 & 0.00 & 100.00 & 0.00 \\
73.21 & $11.32 \pm 0.05$ & 100.00 & 0.00 & 100.00 & 0.00 & 100.00 & 0.00 \\
58.5 & $11.22 \pm 0.04$ & 100.00 & 0.00 & 100.00 & 0.00 & 100.00 & 0.00 \\
46.8 & $11.13 \pm 0.03$ & 100.00 & 0.00 & 100.00 & 0.00 & 100.00 & 0.00 \\
37.5 & $11.03 \pm 0.04$ & 94.33 & 1.44 & 100.00 & 0.00 & 100.00 & 0.00 \\
30 & $10.93 \pm 0.07$ & 78.5 & 1.87 & 97.50 & 2.46 & 92.82 & 3.62 \\
25 & $10.85 \pm 0.03$ & 40.49 & 5.23 & 45.94 & 7.66 & 30.63 & 6.72 \\
18 & $10.71 \pm 0.02$ & 18.11 & 12.43 & 6.25 & 2.55 & 1.25 & 1.62 \\
14.4 & $10.61 \pm 0.04$ & 4.64 & 1.44 & 0.63 & 1.32 & 0.31 & 0.99 \\
Control & $7.00 \pm 0.02$ & 0.51 & 1.14 & 0.31 & 0.99 & 0.31 & 0.99 \\
\hline
\end{tabular}

\subsection{Culture Techniques and Experimental Procedures on Daphnia magna}

Daphnia were cultured in glass tanks filled with $2 \mathrm{~L}$ of aerated, reconstituted, moderately hard water. The colony was maintained at $21-23^{\circ} \mathrm{C}$ in a chamber with a photoperiod of $12 \mathrm{~h} \mathrm{light} / 12 \mathrm{~h}$ dark. Daphnia were fed $10 \mathrm{~mL}$ of Scenedesmus sp. algae (with a density between 32-36 $\times 10^{6} \frac{\mathrm{cell}}{\mathrm{mL}}$ of algae). Neonates were separated from adults based on their size $(<1.5 \mathrm{~mm})$ by sieving. The bioassays were conducted in $120 \mathrm{~mL}$ polystyrene containers, with $100 \mathrm{~mL}$ of toxicant solution in each. Thirty-two neonates were transferred to containers containing different concentrations of the test pollutants. There was no feeding and no aeration during the tests. In OECD standards it is recommended to apply at least five, but generally 10, organisms per test vessel, and there are no obstacles to use 32 organisms for better statistical analysis. At least $2 \mathrm{~mL}$ of test solution should be provided for each animal (i.e., a volume of $10 \mathrm{~mL}$ for five daphnids per test vessel). In our experiment, for each individual, more than $3 \mathrm{~mL}$ test solution was used.

Dead individuals were identified visually after $24 \mathrm{~h}$. For each tested population, control group and suitable number of toxicant solution concentrations were used to determine $\mathrm{EC}_{50}$ and the experiments were repeated in 10 replications for each toxicant concentration [41,42].

The parameters of the water used in the preparation of experimental solutions are enclosed in Appendix Table A1.

\subsection{Evaluation of Toxicity Tests and Statistical Analysis}

The toxicity of the tested substances was classified according to three widely used scales: Dockal and Sold [43], European Union, and US EPA (The Environmental Protection Agency). The assessment of toxicity impact was supported by microscopic observations, using a Nikon Eclipse 1200 Research Light Microscope (LM) with a digital camera (Nikon Instruments Europe BV, Amsterdam, The Netherlands).

The STATISTICA software (verion. 12, StatSoft Polska, Krakow, Poland) package was used to analyze the data. The test applied was ANOVA; two or more of the observed proportion mortalities had to be between zero and one. The probit method was used as a parametric statistical procedure to estimate $\mathrm{LC}_{50}$ and the associated $95 \%$ confidence interval [44]. I was assumed a standard level of significance 0.05 to determine statistical significance.

\section{Results}

\subsection{Results of Acute Toxicity Tests}

The $24 \mathrm{~h}$ acute toxicity tests were conducted to assess the response of the species studied to acidification and ammonium hydroxide. Mortality of Lymnaea stagnalis (embryonic and juvenile forms) in comparison to Daphnia magna (neonates) was tested for different concentrations of sulfuric acid (Table 2), nitric acid (Table 3), and ammonium hydroxide solution (Table 4). These tables show concentrations causing a total lethal effect $\left(\mathrm{LC}_{100}\right.$, mortality rate of $\left.100 \%\right)$ and concentrations which 
exhibited no toxic effect within $24 \mathrm{~h}$ (mortality at the control level). Sensitivity of Daphnia magna was generally lower than that of Lymnaea stagnalis subjected to the stress of all of the tested substances. Nevertheless, the rank of toxicity of the three substances was analogous for Daphnia magna and Lymnaea stagnalis; the most toxic of the three was ammonium hydroxide, followed by sulfuric acid and nitric acid (Tables 2-4).

The $\mathrm{LC}_{50}$ values confirmed that ammonium hydroxide was the most toxic substance for Lymnaea stagnalis; the $\mathrm{LC}_{50} / 24 \mathrm{~h}$ was $24.27 \mathrm{mg} \cdot \mathrm{dm}^{-3}(\mathrm{pH}=10.84)$ for embryos and $24.72(\mathrm{pH}=10.85)$ for juveniles (Tables 5-7, Figure 3). The toxicity of both acids was lower for both forms of Lymnaea stagnalis. Embryonic forms were more sensitive than juvenile ones. The $\mathrm{LC}_{50} / 24 \mathrm{~h}$ for Lymnaea stagnalis embryos was $81.17(\mathrm{pH}=2.78) \mathrm{mg} \cdot \mathrm{dm}^{-3}$ in the sulfuric acid solution and $105.19 \mathrm{mg} \cdot \mathrm{dm}^{-3}(\mathrm{pH}=2.78)$ in the nitric acid solution (Table 5). For juvenile Lymnaea stagnalis the $\mathrm{LC}_{50} / 24 \mathrm{~h}$ of the sulfuric acid was $126.49 \mathrm{mg} \cdot \mathrm{dm}^{-3}(\mathrm{pH}=2.59)$ and that of the nitric acid was $170.47 \mathrm{mg} \cdot \mathrm{dm}^{-3}(\mathrm{pH}=2.57)$ (Table 6).

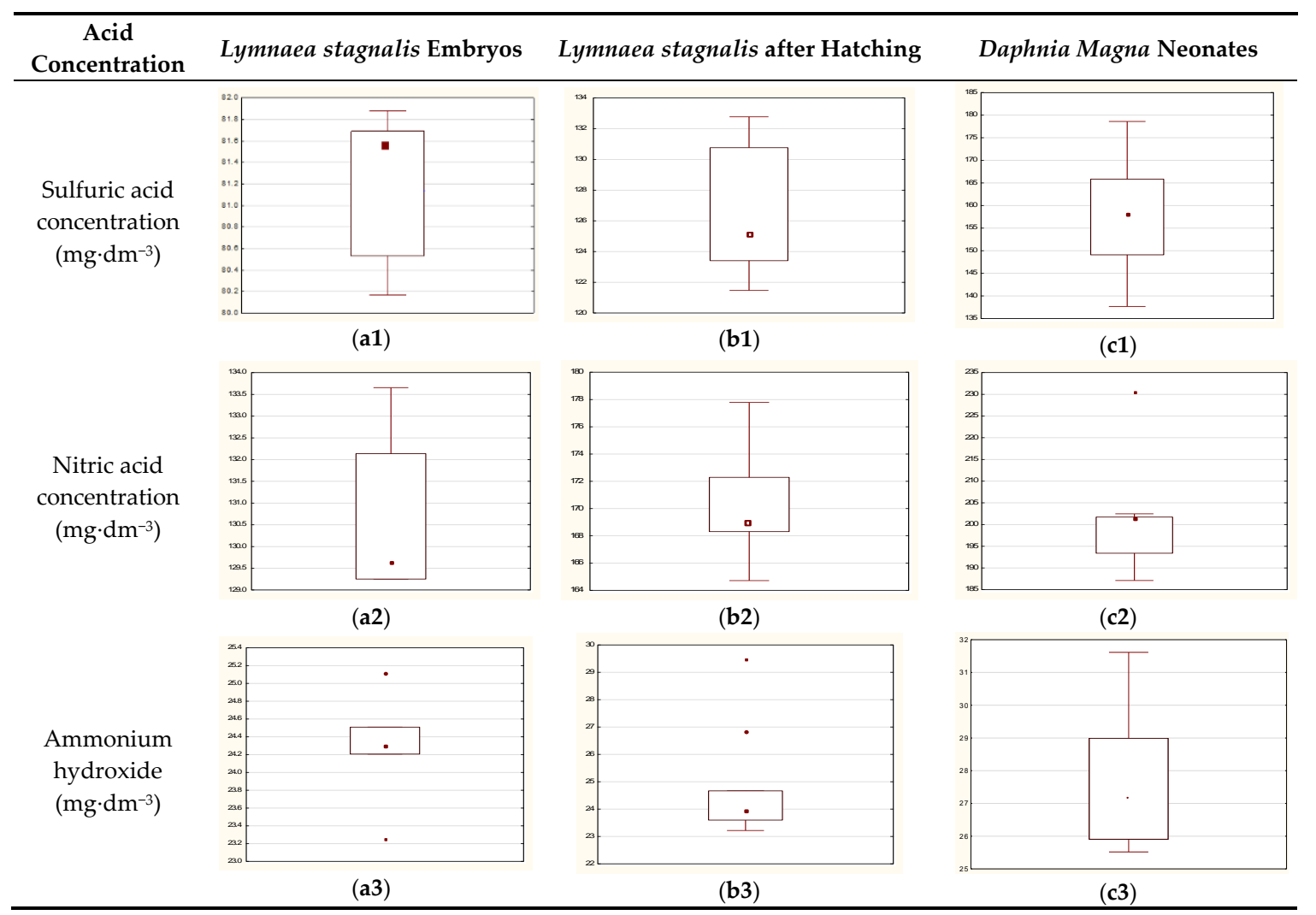

Figure 3. $\mathrm{LC}_{50}(24 \mathrm{~h})$ values for selected bioindicators exposed to various concentrations of stressors: (a) Lymnaea stagnalis embryos; (b) Lymnaea stagnalis juvenile forms; and (c) Daphnia magna neonates Legend: median (plot central point), $25 \%-75 \%$ (box), non-outlier value (whiskers), and outlying points (extreme values).

Table 5. Assessment of acute toxicity of pollutants on Lymnaea stagnalis embryos $\left(\mathrm{LC}_{50} / 24 \mathrm{~h}\right)$ Lymnaea stagnalis juveniles after hatching.

\begin{tabular}{ccccc}
\hline \multirow{2}{*}{ Substance } & \multirow{2}{*}{$\begin{array}{c}\text { LC Value (Lymnaea stagnalis } \\
\text { Embryos) Mean } \pm \text { SD }\end{array}$} & \multicolumn{3}{c}{ Toxicity Class According to: } \\
\cline { 3 - 5 } & & Dockal and Sold & European Union & US EPA \\
\hline $\mathrm{H}_{2} \mathrm{SO} 4$ & $81.17 \pm 0.76 \mathrm{mg} \cdot \mathrm{dm}^{-3}$ & Average toxicity & Harmful & Moderate toxicity \\
$\mathrm{HNO}_{3}$ & $105.19 \pm 1.54 \mathrm{mg} \cdot \mathrm{dm}^{-3}$ & Low toxicity & - & Low toxicity \\
$\mathrm{NH}_{4} \mathrm{OH}$ & $24.27 \pm 0.68 \mathrm{mg} \cdot \mathrm{dm}^{-3}$ & Average toxicity & Harmful & Moderate toxicity \\
\hline
\end{tabular}


Table 6. Assessment of acute toxicity of pollutants on Lymnaea stagnalis after hatching $\left(\mathrm{LC}_{50} / 24 \mathrm{~h}\right)$.

\begin{tabular}{ccccc}
\hline \multirow{2}{*}{ Substance } & \multirow{2}{*}{$\begin{array}{c}\text { LC } \\
\text { Juveniles) Mean } \pm \text { SD }\end{array}$} & Dockal and Sold & European Union & US EPA \\
\cline { 3 - 5 } & & Low toxicity & - & Low toxicity \\
$\mathrm{H}_{2} \mathrm{SO}_{4}$ & $126.49 \pm 4.36 \mathrm{mg} \cdot \mathrm{dm}^{-3}$ & Low toxicity & - & Low toxicity \\
$\mathrm{HNO}_{3}$ & $170.47 \pm 4.19 \mathrm{mg} \cdot \mathrm{dm}^{-3}$ & Average toxicity & Harmful & Moderate toxicity \\
$\mathrm{NH}_{4} \mathrm{OH}$ & $24.72 \pm 1.98 \mathrm{mg} \cdot \mathrm{dm}^{-3}$ & AH &
\end{tabular}

Table 7. Assessment of acute toxicity of pollutants on Daphnia magna $\left(\mathrm{LC}_{50} / 24 \mathrm{~h}\right)$.

\begin{tabular}{ccccc}
\hline \multirow{2}{*}{ Substance } & \multirow{2}{*}{$\begin{array}{c}\text { LC } \\
\end{array}$} & Mean \pm SD & \multicolumn{3}{c}{ Toxicity Class According to: } \\
\cline { 3 - 4 } & & Dockal \& Sold & European Union & US EPA \\
\hline $\mathrm{H}_{2} \mathrm{SO}_{4}$ & $156.09 \pm 12.39 \mathrm{mg} \cdot \mathrm{dm}^{-3}$ & Low toxicity & - & Low toxicity \\
$\mathrm{HNO}_{3}$ & $200.82 \pm 6.31 \mathrm{mg} \cdot \mathrm{dm}^{-3}$ & Low toxicity & - & Low toxicity \\
$\mathrm{NH}_{4} \mathrm{OH}$ & $27.62 \pm 2.03 \mathrm{mg} \cdot \mathrm{dm}^{-3}$ & Average toxicity & Harmful & Moderate toxicity \\
\hline
\end{tabular}

During the bioassay the quantitative evaluation was conducted in parallel with qualitative microscopic observations. A rapid process of biological immobilization was observed as the effect of increasing toxicant concentrations. Numerous organisms died within 10-45 min. After $24 \mathrm{~h}$ an intensified process of disintegration and destruction was observed under the microscope (Figure 4). All of the bioindicators tested showed a similar reaction leading to disintegration and denaturation of proteins and other organic compounds. Disintegration of the bodies was much greater under ammonium hydroxide stress than in the case of the other toxins. A very distinctive toxicity effect was observed, such as white opacity of snail eggs. In the case of juvenile forms of Lymnaea stagnalis and Daphnia magna, progressive disintegration of tissues was noted.

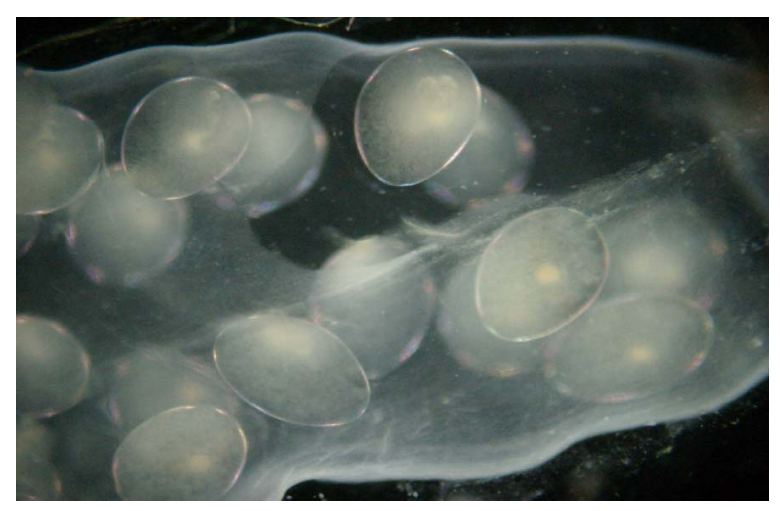

Figure 4. Embryos in eggs after 24 expositions in nitric acid solution, concentration $=228 \mathrm{mg} \cdot \mathrm{dm}^{3}$.

\subsection{Comparison of the Sensitivity of the Organisms to the Toxicants}

Based on the $\mathrm{LC}_{50}$ values the toxicity of the tested substances for Lymnaea stagnalis was classified (Tables 5 and 6) and compared with Daphnia magna (Table 7, Figure 5). Results were very similar in terms of the class of toxicity according to the three commonly adopted scales (Dockal and Sold, EU, and US EPA). The solutions of sulfate and nitrate ions showed lower toxicity (low and moderate toxicity) for all of the bioindicators, whereas ammonia was moderate (Dockal and Sold and US EPA) or even harmful according to the EU criteria.

The results of one-way analysis of variance did not allow us to reject the hypothesis that there are no differences between the organisms tested exposed to the substances applied (Table 8). All of the organisms showed similar degrees of sensitivity to the substances. Thus, they can be used interchangeably in toxicity tests for these substances. 


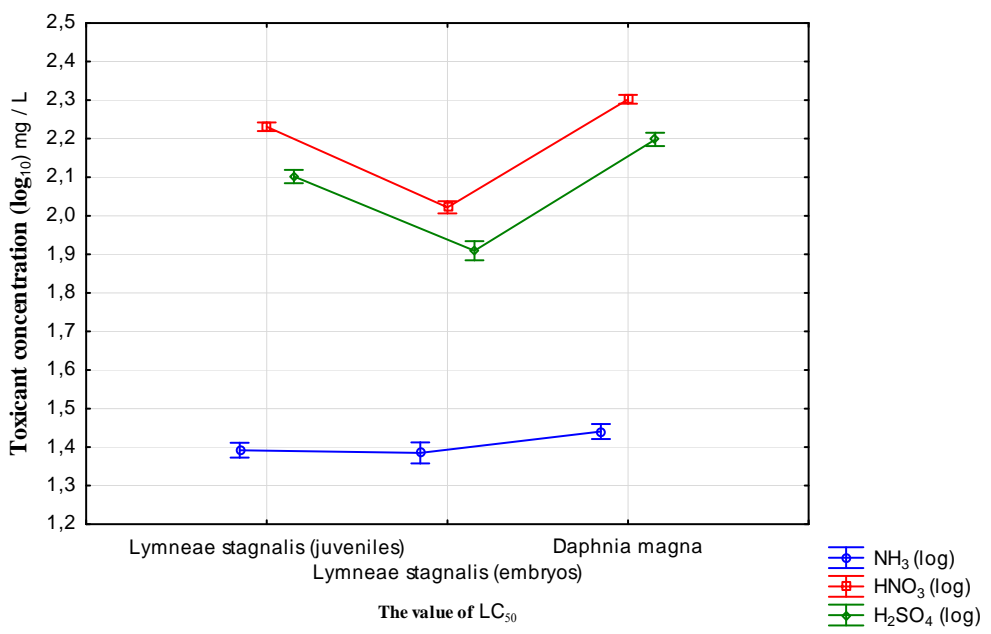

Figure 5. Comparison of $\mathrm{LC}_{50}$ values of pollutants for selected bioindicators (standard error).

Table 8. Results of one-way ANOVA.

\begin{tabular}{cccccc}
\hline Parameters & SS & Degrees of Freedom & MS & F & P \\
\hline Absolute term & 1198.74 & 1 & 1198.74 & 1688.30 & 0.0 \\
Bioindicators & 2.23 & 2 & 1.11 & 1.573 & 0.21 \\
Error & 46.86 & 66 & 0.71 & - & - \\
\hline
\end{tabular}

Post hoc test-Tukey's HSD test (Honest Significant Difference); significance of differences between test organisms was assessed (Table 5).

The post hoc (Tukey's) tests confirmed that all the bioindicators responded similarly to the substances tested. The statistical analysis revealed no statistically significant differences between them (Table 9).

Table 9. Results of Tukey's HSD test for significance of differences between the organisms tested.

\begin{tabular}{cccc}
\hline Bioindicators & L. stagnalis (Juveniles) & L. stagnalis (Embryos) & D. magna \\
\hline L. stagnalis (juveniles) & - & 0.49 & 0.78 \\
L. stagnalis (embryos) & 0.49 & - & 0.19 \\
D. magna & 0.78 & 0.19 & - \\
\hline
\end{tabular}

\section{Discussion}

The completed experiment using developmental stages of Lymnaea stagnalis revealed their high potential as a new bioassay for common water pollutants. Recent decades have seen continual progress in the testing of biomonitoring methods (especially acute toxicity tests) for surface water samples. Nevertheless, use of these methods in practice is still limited [45-50] Lymnaea stagnalis is a widespread species found throughout Europe, Northern Asia and North America [41]. It is noteworthy that this species can be found in still or slow-moving waters [51,52]. Features such as its common occurrence and tolerance for different types of habitats suggest that Lymnaea stagnalis is exceptionally well-suited for environmental monitoring.

The proposed new toxicity bioassay can be widely used to evaluate water degradation-both acidification and alkalization. As Lymnaea stagnalis showed great sensitivity to acid, it can be extensively used as a bioindicator in toxicological examination of water with low $\mathrm{pH}$. Its response to acidification is also pronounced, and it is more sensitive to a sulfuric acid solution than to nitric acid. The value of $\mathrm{pH}$ was additionally measured by the parameters, together with the concentration of used toxicants, so the primary toxicity action is strongly dependent on the ion form of the used toxicant and $\mathrm{pH}$ value. For the 
used chemical compounds, $\mathrm{HNO}_{3} \mathrm{pKa}=-2, \mathrm{Ka}=100 \%, \mathrm{H}_{2} \mathrm{SO}_{4} \mathrm{pKa}=-6.62, \mathrm{Ka}=4.17 \times 10^{6}$, and for $\mathrm{NH}_{4} \mathrm{OH}$ is $100 \%$ ionization in water. This means that almost $100 \%$ of the molecule is broken down into its constituent ions. We observed toxic action of these ions depending on their concentrations, and the rate of $\mathrm{pH}$ indirectly affects osmosis. Hence, it can be widely used for biomonitoring of surface water quality in areas threatened by acid deposition from anthropogenic sources, caused by release of $\mathrm{NO}_{x}$ and $\mathrm{SO}_{2}$ into the atmosphere. These emissions are currently regarded as one of the most widespread global threats, and a major implication of them is acidification of the aquatic environment $[38,39]$.

The use of early developmental stages of Lymnaea stagnalis increases the choice of acute toxicity bioassay methods for quick and quantified assessment of surface water quality. The most important symptoms of toxicity include delayed development in low concentrations of the water pollutants tested. This process has been observed before, e.g., [ $43,53,54]$ stress caused by environmental pollution reduces the energy budget of the organism. Exposed organisms spend a relatively large portion of their energy resources on decontamination and defense against the toxic influence of pollutants. In this situation the amount of energy that can be spent on growth and development is reduced. Higher concentrations of all the tested toxins have a similar influence on aquatic organisms. The aggressive action of strong acids and hydroxides on biochemical structures causes protein denaturation. Changes in the properties of cellular membranes occurring at high concentrations of these substances disintegrate the plasmalemma. The final effect of stress includes damage to the organisms and their death [19]. The great pond snail is a very sensitive bioindicator, facilitating detection of even very low levels of environmental stress factors. Compared with Daphnia magna, relatively low concentrations of toxicants caused a lethal effect in early developmental stages of Lymnaea stagnalis. In an increased range of concentrations of acid anions and ammonia cations, the process of immobilization is very rapid, with individuals dying within 10-45 min. After $24 \mathrm{~h}$ very severe disintegration and destruction can be observed.

Toxic action can also be detected as changes in the surface morphology of Lymnaea stagnalis that can be observed microscopically (Figure 6). Maceration of cocoon envelopes accelerates the direct exposure of embryos developing in eggs to selected toxicants. The cocoon envelopes reduce embryos exposed to selected water xenobiotics. They stabilize the internal environment of developing embryos. Proper maceration technique by scalpel eliminates the cocoon's barrier effect and increases bioassay sensitivity. All of the above-mentioned substances act aggressively and cause serious damage in the form of progressive tissue disintegration. Damage caused by acids, and that caused by ammonia, are distinguishable by their specific appearance, and can be distinguished by microscopic observations from the effects of other substances, such as detergents [43]. The response of immobilized organisms (both snails and daphnids) during the experiments was very characteristic. Their bodies became opaquely white, and juvenile forms showed progressive disintegration of tissues (depending on the concentration and exposure time).

The experiment showed that Lymnaea stagnalis has numerous advantages as a bioindicator, during both embryonic and juvenile development. The embryonic form of this snail is more sensitive to pollution than the juvenile form. Scientific evidence clearly indicates the need to use embryonic stages and juveniles of various aquatic organisms after hatching in water bioindication, as highly-sensitive bioindicators of the toxicity of various ecotoxins [55].

It is noteworthy that Lymnaea stagnalis showed an analogous response to that of Daphnia magna. The Daphnia magna bioassay is one the most commonly used bioassays worldwide for acute toxicity testing of various chemical substances [56]. Moreover, toxicity values between Daphnia and many other aquatic organisms are known to be strongly correlated, especially in the case of fish. Toxicity evaluation of the toxicants discussed above can be used interchangeably with other bioassays or together in a battery of bioassays for comprehensive bioindication [57].

Laboratory studies have shown that Lymnaea stagnalis (embryonic and juvenile forms (immediately after hatching) is a good bioindicator fulfilling the 5R criterion [58]: it is relevant, reliable, robust, responsive, and reproducible. The bioassay with embryos and juveniles of Lymnaea stagnalis gives very similar results, and we can base on them in the interpretation of toxic effects caused by water toxicants. 
Moreover, our results are an answer to the long search for sensitive and low-cost bioassays for testing surface water toxicity [59,60]. Since Lymnaea stagnalis is common and easy to breed and raise, its use is not costly. We plan to conduct further tests on this organism to develop a detailed technique for its use in laboratories carrying out environmental monitoring.

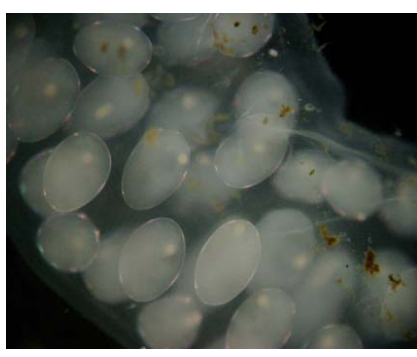

(a)

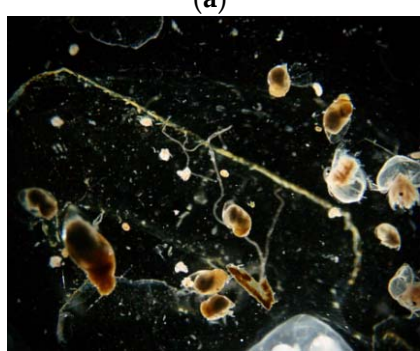

(d)

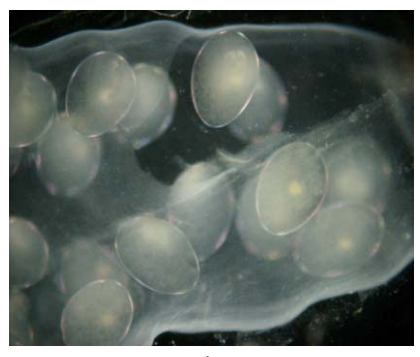

(b)

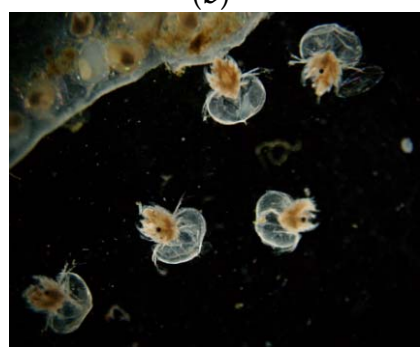

(e)

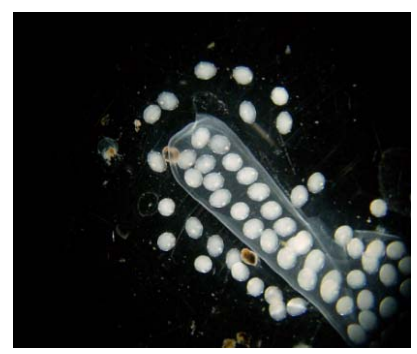

(c)

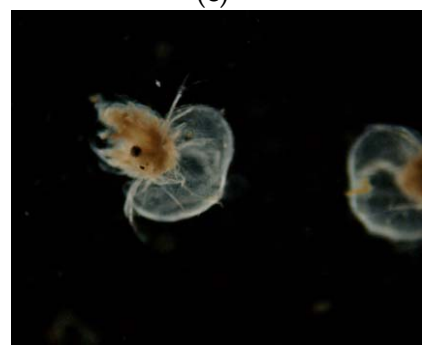

(f)

Figure 6. Visible changes caused by the effect of acids on organisms. (a-c) Embryos of Lymnaea stagnalis; (d) hatchlings of Lymnaea stagnalis; and (e,f) Daphnia magna.

The research on the new objective and sensitive biotest with the application of embryonic and juvenile Lymnaea stagnalis [61] continues. In the future it will be validated and directives will be established for the laboratory procedures of the biotest (OECD, ISO etc.).

Moreover, the bioassays use embryonic and juvenile forms which are small. The bioassay can be performed even in small containers $(120 \mathrm{~mL})$ on a large group of individuals, enabling statistical testing with 3-5 organisms per $10 \mathrm{~mL}$ of test solution. Due to their high breeding rate, Lymnaea stagnalis specimens are available for laboratory bioassays throughout the year.

The proposed organisms can be used in bioassay batteries to detect environmental effects of selected chemicals and their mixtures. This approach is recommended by the US EPA and APHA (American Public Health Association) [62], as well as the EU. The biotests presented in this study can be applied to examine water samples both taken from the water bodies suspected of acidification or ammonia intoxication, as well as in testing the quality of treated wastewater [53,54]. In water monitoring one of the most important criteria is biological assessment. Thus, the biotests designed here can be included into the system of biomonitoring as a tool for better assessment of water quality.

\section{Conclusions}

Lymnaea stagnalis is a very sensitive bioindicator capable of detecting even very low levels of environmental stressors. The test procedures are simple and inexpensive, and make it possible to detect negative effects of both acidification and alkalization. These organisms can be used in a battery of bioassays.

The experiment revealed that Lymnaea stagnalis, during both embryonic and juvenile development, has numerous advantages as a bioindicator.

Lymnaea stagnalis shows a similar response to that of Daphnia magna, with the values of $\mathrm{LC}_{50}$ were on a similar levels. 
The toxic action can also be detected as changes in the surface morphology of Lymnaea stagnalis which can be observed microscopically.

The study showed that the early developmental stages of Lymnaea stagnalis are good bioindicators that may be used in monitoring surface water quality.

Lymnaea stagnalis is a species that is easy to obtain, representative for the majority of fresh water areas and, thus, meets the requirements for bioindicators.

The easiness of breeding in laboratory, high reproduction, and large amount of embryonic and juvenile forms for the tests allows the statistical assessment of toxic effects in large statistical groups.

The proposed biotest is based on organisms from the group of aquatic invertebrates (mollusks) and increases the number of bioindicators, which can be widely applied in the batteries of biotests for better assessment of negative impact of different water pollutants.

Acknowledgments: The research was realized within the Project No. DS-3337/KEKiOP, financed from the research grant allocated by the Ministry of Science and Higher Education.

Author Contributions: This study was designed by Robert Mazur and Wu Shubiao. Krzysztof Szoszkiewicz, and Robert Mazur performed the data collection and also analysis. The manuscript was prepared by Robert Mazur and Dawid Bedla and revised by Wu Shubiao and Agata Nowak.

Conflicts of Interest: The authors declare no conflict of interest.

\section{Appendix A}

Table A1. Chemical parameters of water used for experiment media preparation.

\begin{tabular}{|c|c|c|c|c|c|c|}
\hline \multirow{2}{*}{ No. } & \multirow{2}{*}{ Water Quality Indicators } & \multirow{2}{*}{ Unit } & \multirow{2}{*}{ Value } & \multicolumn{3}{|c|}{ HAC } \\
\hline & & & & $P 1^{1}$ & EU $^{2}$ & $\mathrm{WHO}^{3}$ \\
\hline 1 & The color & $\mathrm{mg} / \mathrm{dm}^{3}$ & 1 & $\mathrm{NAC}^{4}$ & $\mathrm{NAC}^{4}$ & 15 \\
\hline 2 & Turbidity & NTU & 0.07 & 1 & accepted & 5 \\
\hline 3 & $\mathrm{pH}$ & - & 7.0 & $6.5-9.5$ & $6.5-9.5$ & - \\
\hline 4 & Conductivity $25^{\circ} \mathrm{C}$ & $\mu \mathrm{S} / \mathrm{cm}$ & 322 & 2500 & 2500 & - \\
\hline 5 & Oxidizability in $\mathrm{KMnO}_{4}$ & $\mathrm{mg} / \mathrm{dm}^{3}$ & 0.7 & 5 & 5 & - \\
\hline 6 & Chlorides & $\mathrm{mg} / \mathrm{dm}^{3}$ & 7.3 & 250 & 250 & 250 \\
\hline 7 & Ammonium ions & $\mathrm{mg} / \mathrm{dm}^{3}$ & 0.018 & 0.5 & 0.5 & 1.5 \\
\hline 8 & Nitrites & $\mathrm{mg} / \mathrm{dm}^{3}$ & $<0.01$ & 0.5 & 0.5 & 3 \\
\hline 9 & Nitrates & $\mathrm{mg} / \mathrm{dm}^{3}$ & 2.2 & 50 & 50 & 50 \\
\hline 10 & Sulfates & $\mathrm{mg} / \mathrm{dm}^{3}$ & 12 & 250 & 250 & 205 \\
\hline 11 & Total hardness & $\mathrm{mg} / \mathrm{dm}^{3}$ & 90 & $60-500$ & - & - \\
\hline 12 & Calcium & $\mathrm{mg} / \mathrm{dm}^{3}$ & 7 & - & - & - \\
\hline 13 & Magnesium & $\mathrm{mg} / \mathrm{dm}^{3}$ & 5.5 & 125 & - & - \\
\hline 14 & Total iron & $\mathrm{mg} / \mathrm{dm}^{3}$ & $<0.025$ & 0.2 & 0.2 & 0.3 \\
\hline 15 & Mangan & $\mathrm{mg} / \mathrm{dm}^{3}$ & $<0.002$ & 0.05 & 0.05 & 0.5 \\
\hline 16 & Copper & $\mathrm{mg} / \mathrm{dm}^{3}$ & $<0.003$ & 2 & 2 & 2 \\
\hline 17 & Chromium & $\mathrm{mg} / \mathrm{dm}^{3}$ & $<0.002$ & 0.05 & 0.05 & 0.05 \\
\hline 18 & Nickel & $\mathrm{mg} / \mathrm{dm}^{3}$ & $<0.0025$ & 0.02 & 0.02 & 0.02 \\
\hline 19 & Cadmium & $\mathrm{mg} / \mathrm{dm}^{3}$ & $<0.00045$ & 0.005 & 0.005 & 0.003 \\
\hline 20 & The SUM of 4 THMs 5 & $\mu \mathrm{g} / \mathrm{dm}^{3}$ & $<0.3$ & 100 & 100 & - \\
\hline 21 & Chloroform & $\mu \mathrm{g} / \mathrm{dm}^{3}$ & $<0.3$ & 30 & - & 200 \\
\hline 22 & The SUM of 4 PAHS ${ }^{5}$ & $\mu \mathrm{g} / \mathrm{dm}^{3}$ & $<0.003$ & 0.1 & 0.1 & - \\
\hline 23 & Benzo pyrene & $\mu \mathrm{g} / \mathrm{dm}^{3}$ & $<0.003$ & 0.01 & 0.01 & - \\
\hline 24 & Coliform Bacteria & $\mathrm{cfu}^{6} / 100 \mathrm{~mL}$ & 0 & 0 & 0 & 0 \\
\hline 25 & Escherichia coli & $\mathrm{cfu}^{6} / 100 \mathrm{~mL}$ & 0 & 0 & 0 & 0 \\
\hline 26 & Enterococcus faecalis & $\mathrm{cfu}^{6} / 100 \mathrm{~mL}$ & 0 & 0 & 0 & - \\
\hline 27 & Clostridium perfringens (with spores) & $\mathrm{cfu}^{6} / 100 \mathrm{~mL}$ & 0 & 0 & 0 & - \\
\hline 28 & $\begin{array}{l}\text { The total number of micro-organisms on } \\
\text { the agar medium in temp. } 22^{\circ} \mathrm{C}\end{array}$ & $\mathrm{cfu}^{6} / 100 \mathrm{~mL}$ & 1 & $\mathrm{NAC}^{4}$ & $\mathrm{NAC}^{4}$ & - \\
\hline 29 & Free chlorines in dechlorinated tap water & $\mathrm{mg} / \mathrm{dm}^{3}$ & 0.02 & 0.3 & - & - \\
\hline
\end{tabular}




\section{References}

1. Rodhe, H. Acidification in a global perspective. Ambio 1989, 18, 155-160.

2. Sutton, M.A.; Reis, S.; Baker, S.M.H. Atmospheric Ammonia-Detecting Emission Changes and Environmental Impacts; Springer Science \& Business Media: London, UK, 2008.

3. National Acid Precipitation Assessment Program. Interim Report; National Acid Precipitation Assessment Program: Washington, DC, USA, 1987; Volume 4, p. 925.

4. Samiullah, Y. Biological Monitoring of Environmental Contaminants: Animals; GEMS-Monitoring and Assessment Centre, King's College London, University of London: London, UK, 1990.

5. Davies, J.J.L.; Jenkins, A.; Monteith, D.T.; Evans, C.D.; Cooper, D.M. Trends in surface water chemistry of acidified UK Freshwaters 1988-2002. Environ. Pollut. 2005, 137, 27-39. [CrossRef] [PubMed]

6. Driscoll, C.T.; Driscoll, K.M.; Roy, K.M.; Dukett, J. Changes in the chemistry of lakes in the Adirondack region of New York following declines in acidic deposition. Appl. Geochem. 2007, 22, 1181-1188. [CrossRef]

7. Evans, C.D.; Cullen, J.M.; Alewell, C.; Kopacek, J.; Marchetto, A.; Moldan, F.; Prechtel, A.; Rogora, M.; Vesely, J.; Wright, R. Recovery from acidification in European surface waters. Hydrol. Earth Syst. Sci. 2001, 5, 283-297. [CrossRef]

8. Monteith, D.T.; Evans, C.D.; Henrys, P.A.; Simpson, G.L.; Malcolm, I.A. Trends in the hydrochemistry of acid-sensitive surface waters in the UK 1988-2008. Ecol. Indic. 2012, 37, 287-303. [CrossRef]

9. Skjelkvåle, B.L.; Borg, H.; Hindar, A.; Wilander, A. Large scale patterns of chemical recovery in lakes in Norway and Sweden: Importance of seasalt episodes and changes in dissolved organic carbon. Appl. Geochem. 2007, 22, 1174-1180. [CrossRef]

10. Sucker, C.; von Wilpert, K.; Puhlmann, H. Acidification reversal in low mountain range streams of Germany. Environ. Monit. Assess. 2011, 174, 65-89. [CrossRef] [PubMed]

11. Warby, R.A.F.; Johnson, C.E.; Driscoll, C.T. Changes in aluminum concentrations and speciation in lakes across the Northeastern US following reductions in acidic deposition. Environ. Sci. Technol. 2008, 42, 8668-8674. [CrossRef] [PubMed]

12. Eriksson, M.O.G. Acidification of Lakes: Effects on Water Birds in Sweden. Available online: http://www. jstor.org/stable/4313038 (access on 13 July 2016).

13. Freda, J. The influence of acidic pond water on amphibians: A review. Water Air Soil Pollut. 1986, 30, 439-450. [CrossRef]

14. Haines, T.A.; Baker, J.P. Evidence of fish population responses to acidification in the eastern United States. Water Air Soil Pollut. 1986, 31, 605-629. [CrossRef]

15. Harriman, R.; Morrison, B.R.S.; Caines, L.A.; Collen, P.; Watt, A.W. Long-term changes in fish populations of acid streams and lochs in Galloway, south-west Scotland. Water Air Soil Pollut. 1987, 32, 89-112. [CrossRef]

16. Pfleger, V.; Chatfield, J. A Guide to Snails of Britain and Europe; The Hamlyn Publishing Group Ltd.: London, UK, 1983; p. 213.

17. Mierle, G.; Clark, K.; France, R. The impact of acidification on aquatic biota in North America: A comparison of field and laboratory results. Water Air Soil Pollut. 1986, 31, 1647-1658. [CrossRef]

18. Muniz, I.P.; Seip, H.M.; Sevaldrud, I.H. Relationship between fish populations and $\mathrm{pH}$ for lakes in southernmost Norway. Water Air Soil Pollut. 1984, 23, 97-113. [CrossRef]

19. Ökland, J.; Ökland, K.A. The effects of acid deposition on benthic animals in lakes and streams. Experientia 1986, 42, 471-486. [CrossRef]

20. Ormerod, S.J.; Allinson, N.; Hudson, D.; Tyler, S.J. The distribution of breeding dippers in relation to stream acidity in upland Wales. Freshw. Biol. 1986, 16, 501-507. [CrossRef]

21. Rosseland, B.O.; Skogheim, O.K.; Sevaldrud, I.H. Acid deposition and effects in Nordic Europe. Damage to fish populations continue apace. Water Air Soil Pollut. 1986, 30, 65-74. [CrossRef]

22. Stokes, P.M. Ecological effects of acidification on primary producers in aquatic systems. Water Air Soil Pollut. 1986, 300, 421-438. [CrossRef]

23. Heleno, R.; Devoto, M.; Pocock, M. Connectance of species interaction networks and conservation value. Ecol. Indic. 2012, 14, 7-10. [CrossRef]

24. Locke, A.; Sprules, W.G. Effects of lake acidification and recovery on the stability of zooplankton food webs. Ecology 1994, 75, 498-506. [CrossRef] 
25. Sutcliffe, D.W.; Hildrew, A.G. Invertebrates Communities in Acid Streams, Acid Toxicity and Aquatic Animals; Seminar Series 34; Mirris, R., Taylor, E.W., Brown, D.J.A., Brown, J.A., Eds.; Cambridge University Press: Cambridge, UK, 1989.

26. Adelman, I.R.; Kusilek, L.I.; Koehle, J.; Hess, J. Acute and chronic toxicity of ammonia, nitrite, and nitrate to the endangered Topeka shiner (Notropis topeka) and fathead minnows (Pimephales promelas). Environ. Toxicol. Chem. 2009, 28, 2216-2223. [CrossRef] [PubMed]

27. Armstrong, B.M.; Lazorchak, J.M.; Murphy, C.H.A.; Haring, H.J.; Jensen, K.M.; Smith, M.E. Determining the effects of ammonia on fathead minnow (Pimephales promelas) reproduction. Sci. Total Environ. 2012, 420, 127-133. [CrossRef] [PubMed]

28. Fairchild, J.F.; Allert, A.L.; Sappington, L.C.; Waddell, B. Chronic toxicity of un-ionized ammonia to early life-stages of endangered Colorado pike minnow (Ptychocheilus lucius) and razorback sucker (Xyrauchen texanus) compared to the surrogate fathead minnow (Pimephales promelas). Arch. Environ. Contam. Toxicol. 2005, 49, 378-384. [CrossRef] [PubMed]

29. Sinha, A.K.; Liew, H.J.; Diricx, M.; Kumar, V.; Darras, V.M.; Blust, R.; De Boeck, G. Combined effects of high environmental ammonia, starvation and exercise on hormonal and ion-regulatory response in goldfish (Carassius auratus L.). Aquat Toxicol. 2012, 114-115, 153-64. [CrossRef] [PubMed]

30. Havas, M. Physiological response of aquatic animals to low $\mathrm{pH}$. In Proceedings of the Symposium on Effects of Acid Precipitation on Benthos, Hamilton, NY, USA, 8-9 August 1980; pp. 49-65.

31. Kroglund, F.; Rosseland, B.O.; Salbu, B.; Kristensen, T.; Finstad, B. Water quality limits for Atlantic salmon (Salmo salar L.) exposed to short term reductions in $\mathrm{pH}$ and increased aluminium simulating episodes. Hydrol. Earth Syst. Sci. 2007, 12, 3317-3355. [CrossRef]

32. Malcolm, I.A.; Bacon, P.J.; Middlemas, S.J.; Fryer, R.J.; Shilland, E.M.; Collen, P. Relationships between hydrochemistry and the presence of juvenile (Salmo trutta) in headwater streams recovering from acidification. Ecol. Indic. 2012, 37. [CrossRef]

33. Driscoll, C.T.; Baker, J.P.; Bisogni, J.J.; Schofield, C.L. Effect of aluminum speciation on fish in dilute acidified waters. Nature 1980, 284, 161-164. [CrossRef]

34. Mazur, R. The application of embryological and ecotoxicological criteria in new methods of environmental biomonitoring. Pol. J. Environ. Stud. 2004, 13, 60-62.

35. Mazur, R.; Lewicki, P. Application of the computer image analyses in the embryo tests as a new method of water biomonitoring. Pol. J. Environ. Stud. 2008, 17, 409-412.

36. Pierce, B.A. The effects of acid precipitation on amphibians. Ecotoxicology 1993, 2, 65-77. [CrossRef] [PubMed]

37. Ohrel, R.; Register, K.M. Volunteer Estuary Monitoring: A Methods Manual; EPA: Washington, DC, USA, 2006.

38. Fan, Y.F.; Hu, Z.Q.; Liu, J. Application of ultrasonic wave technology to evaluate the corrosion depth of concrete in acid rain environment. Adv. Mater. Res. 2010, 129-131, 128-133. [CrossRef]

39. Lv, Y.; Wang, C.; Jia, Y.; Wang, W.; Ma, X.; Du, J.; Pu, G.; Tian, X. Effects of sulfuric, nitric, and mixed acid rain on litter decomposition, soil microbial biomass, and enzyme activities in subtropical forests of China. Appl. Soil Ecol. 2014, 79, 1-9. [CrossRef]

40. Jura, C. Invertebrates_Basic Functional Morphology; PWN: Warsaw, Poland, 1996.

41. Tyagi, V.K.; Chopra, A.K.; Durgapal, N.C.; Kumar, A. Evaluation of Daphnia magna as an indicator of toxicity and treatment efficacy of municipal sewage treatment plant. J. Appl. Sci. Environ. Manag. 2007, 11, 1.

42. OECD. OECD Guidelines for the Testing of Chemicals Test No. 211: Daphnia magna Reproduction Test; Section 2; OECD Publishing: Paris, France, 2012.

43. Mazur, R.; Wagner, A.; Zhou, M. The application of the Lymnaea stagnalis embryo-test in the toxicity bioindication of surfactants in fresh waters. Ecol. Indic. 2013, 30, 190-195. [CrossRef]

44. Finney, D.J. Statistical Method in Biological Assay, 3rd ed.; Charles Griffin \& Co. Ltd.: London, UK, $1978 ;$ p. 508.

45. Baran, A.; Tarnawski, M. Phytotoxkit/Phytotestkit and Microtox ${ }^{\circledR}$ as tools for toxicity assessment of sediment. Ecotoxicol. Environ. Saf. 2013, 98, 19-27. [CrossRef] [PubMed]

46. Huerta Buitrago, B.; Ferrer Muñoz, P.; Ribé, V.; Larsson, M.; Engwall, M.; Wojciechowska, E.; Waara, S. Hazard assessment of sediments from a wetland system for treatment of landfill leachate using bioassays. Ecotoxicol. Environ. Saf. 2013, 97, 255-262. [CrossRef] [PubMed] 
47. Johnson, I. Criteria-based procedure for selecting test methods for effluent testing and its application to Toxkit microbiotests. In New Microbiotests for Routine Toxicity Screening and Biomonitoring; Persoone, G., Janssen, C., De Coen, W., Eds.; Kluwer Academic/Plenum Publishers: New York, NY, USA, 2000; Chapter 7; pp. 73-94.

48. Marsalek, B.; Rojickova-Padrtova, R. Selection of a battery of microbiotests for various purposes-The Czech experience. In New Microbiotests for Routine Toxicity Screening and Biomonitoring; Persoone, G., Janssen, C., De Coen, W., Eds.; Kluwer Academic/Plenum Publishers: New York, NY, USA, 2000; Chapter 2; pp. 95-101.

49. Moreira Dos Santos, M.M.; Persoone, G. The use of Daphnia magna neonates hatched from ephippia for toxicity testing. In New Microbiotests for Routine Toxicity Screening and Biomonitoring; Persoone, G., Janssen, C., De Coen, W., Eds.; Kluwer Academic/Plenum Publishers: New York, NY, USA, 2000; Chapter 13; pp. 145-153.

50. Ruck, J.G.; Martin, M.; Mabon, M. Evaluation of Toxkits as methods for monitoring water quality in New Zealand. In New Microbiotests for Routine Toxicity Screening and Biomonitoring; Persoone, G., Janssen, C., De Coen, W., Eds.; Kluwer Academic/Plenum Publishers: New York, NY, USA, 2000; Chapter 9; pp. 103-119.

51. Rosewarne, P.J.; Mortimer, R.J.G.; Dunn, A.M. Size-dependent impacts of the endangered white-clawed crayfish (Austropotamobius pallipes) (Lereboullet) on the littoral community. Knowl. Manag. Aquat. Ecosyst. 2013, 1-10. [CrossRef]

52. Zhu, B.; Ellis, M.S.; Fancher, K.L.; Rudstam, L.G. Shading as a Control Method for Invasive European Frogbit (Hydrocharis morsus-ranae L.). PLoS ONE 2014, 9, e98488. [CrossRef] [PubMed]

53. Wagner, A. The role of aquatic pulmonates snails in monitoring of water. In XV Polish Malacological Seminar in 23-25 IX; Universitatis Lodziensis: Lodz, Poland, 1999.

54. Wagner, A. Influence of sewage from different water treatment plants in the Cracow Region (Poland) on early developmental stages of water snails. Lakes Reserv. Res. Manag. 2000, 5, 83-88. [CrossRef]

55. OECD. OECD Guidelines for the Testing of Chemicals Test No. 236: Fish Embryo Acute Toxicity (FET) Test; Section 2; OECD Publishing: Paris, France, 2013.

56. Persoone, G.; Baudo, R.; Cotman, M.; Blaise, C.; Thompson, K.C.; Moreira-Santos, M.; Vollat, B.; Törökne, A.; Han, T. Review on the acute Daphnia magna toxicity test-Evaluation of the sensitivity and the precision of assays performed with organisms from laboratory cultures or hatched from dormant eggs. Knowl. Manag. Aquat. Ecosyst. 2009, 393, 1-29. [CrossRef]

57. Pandard, P.; Devillers, J.; Charissou, A.M.; Poulsen, V.; Jourdain, M.J.; Férard, J.F.; Grand, C.; Bispo, A. Selecting a battery of bioassays for ecotoxicological characterization of wastes. Sci. Total Environ. 2006, 363, 114-125. [CrossRef] [PubMed]

58. Walker, C.H.; Hopkin, S.P.; Sibly, R.M.; Peakall, D.B. Principles of Ecotoxicology, 2nd ed.; PWN: Warsaw, Poland, 2002.

59. Bakopoulou, S.; Emmanouil, C.; Kungolos, A. Assessment of wastewater effluent quality in Thessaly region, Greece, for determining its irrigation reuse potential. Ecotoxicol. Environ. Saf. 2011, 74, 188-194. [CrossRef] [PubMed]

60. Lammer, E.; Carr, G.J.; Wendler, K.; Rawlings, J.M.; Belanger, S.E.; Braunbeck, T. Is the fish embryo toxicity test (FET) with the zebrafish (Danio rerio) a potential alternative for the fish acute toxicity test? Comp. Biochem. Physiol. C Toxicol. Pharmacol. 2009, 149, 196-209. [CrossRef] [PubMed]

61. Ducrot, V.; Askem, C.; Azam, D.; Brettschneider, D.; Brown, R.; Charles, S.; Holbech, H. Development and validation of an OECD reproductive toxicity test guideline with the pond snail Lymnaea stagnalis (Mollusca, Gastropoda). Regul. Toxicol. Pharmacol. 2014, 70, 605-614. [CrossRef] [PubMed]

62. Connon, R.E.; Geist, J.; Werner, I. Effect-based tools for monitoring and predicting the ecotoxicological effects of chemicals in the aquatic environment. Sensors 2012, 12, 12741-12771. [CrossRef] [PubMed]

(C) 2016 by the authors; licensee MDPI, Basel, Switzerland. This article is an open access article distributed under the terms and conditions of the Creative Commons Attribution (CC-BY) license (http://creativecommons.org/licenses/by/4.0/). 